\title{
Сучасні підходи до лікування гнійних ран. Невирішені проблеми
}

\author{
V. O. SHAPRYNSKYI, S. S. SKALSKYI, S. V. PALAMARCHUK, YE. V. SHAPRYNSKYI \\ Vinnytsia National Medical University by M. I. Pyrohov
}

MODERN APPROACHES TO TREATMENT OF PURULENT WOUNDS. UNSOLVED PROBLEMS

\begin{abstract}
Комплексне лікування гнійних ран залишається однією з актуальних проблем хірургії. Незважаючи на значні досягнення сучасної фармакології, основним у лікуванні ран залишається хірургічний метод у поєднанні з місцевим лікуванням. В свою чергу, ефективність лікування визначається чітким розумінням патогенезу, фазності ранового процесу, завдань, які необхідно вирішити в кожній із фаз. Арсенал сучасних лікувальних методик дозволяє зробити індивідуальним підхід до кожного з пацієнтів, враховуючи всі переваги та недоліки вибраного методу лікування, супутні та фонові захворювання, наявність протипоказань. Відмова від шаблонів, застосування сучасних підходів, вологого ведення ран покликані скоротити середні строки перебування хворого в стаціонарі, прискорити очищення рани та покращити віддалені наслідки у хворих із гнійними ранами. Актуальним залишається пошук нових, ефективних та водночас простих, ергономічних методів місцевого лікування ран.

Multimodality therapy of purulent wounds remains one of acute issues in surgery. Despite significant achievements in contemporary pharmacology, surgical method combined with local treatment still remains the basic one in wound healing. In turn, the efficiency of the therapy is predetermined by clear understanding of pathogenesis, staging of wound process and problems to be solved at each stage. The store of up-to-date therapeutic methods enables the doctor to apply individual approach to every patient taking into account all advantages and disadvantages of the chosen therapeutic method, accompanying and background diseases as well as possible contraindications. Refusal from template treatment, implementation of modern approaches and moist wound management are aimed at reduction of average period of hospital stay, acceleration of wound cleansing and improvement of long-term effects in patients with purulent wounds. Still, the search for new effective and at the same time simple and ergonomic methods of local treatment of wounds remains a burning issue.
\end{abstract}

За даними вітчизняної та зарубіжної літератури, пацієнти хірургічного профілю з гнійно-запальними захворюваннями складають 35-45 \%, післяопераційні гнійні ускладнення виникають у 24$30 \%$ випадків [1, 4, 21]. На частку інфекцій хірургічної рани припадає до 15 \% усієї кількості внутрішньолікарняних інфекцій. Частка ранової хірургічної інфекції після “чистих" операційних втручань складає 1-6 \% [16], в деяких випадках до $16 \%$ - у разі ургентних операційних втручань [8]. Летальність при хірургічній гнійній інфекції становить від 40 до 60 \%. Відмічається збільшення частки анаеробної мікрофлори при гнійних інфекціях внутрішніх органів - до 70 \% [10] та м'яких тканин - до 10 \% [16]. Рани будь-якого генезу загоюються за єдиним біологічним законам, а це зумовлює і спільність принципів їхнього лікування [10]. Принциповим підходом є патогенетична спрямованість лікування відповідно до фази ранового процесу. Етапи патогенетичного лікування: 1) актив- на хірургічна обробка (дебридмент); 2) додаткова обробка післяопераційної рани; 3) раннє закриття ранового дефекту; 4) дренування рани; 5) загальна та місцева антибактеріальна терапія; 6) застосування імунних препаратів; 7) усунення факторів, що сповільнюють загоєння $[1,10,20]$. Останніми роками відбулись зміни в підходах до лікування інфікованої рани. Необхідність у широкому висічені інфікованих тканин піддають сумніву, особливо при ранах в функціонально “невигідних" зонах та в ділянках з ризиком пошкодження нервів, судин [11]. Дебридмент може бути: 1) хірургічним; 2) механічним (Debrisoft, Shave-терапія); 3) фізичним; 4) хімічним; 5) біологічним [6, 15, 23]. Способи місцевого лікування ран поділяють на дві групи: 1) відкритий спосіб: а) лікування під пов'язкою; б) безпов'язковий метод у керованому абактеріальному середовищі; 2) закритий спосіб накладання первинного шва в умовах адекватного дренування [3, 10]. У першій фазі лікування спря- 
моване на очищення рани, лізис некротичних тканин, дренування ексудату, елімінацію інфекції. Тактика місцевого лікування в другій і третій фазах, як правило, полягає у попередженні реінфікування, механічного i гіперосмотичного пошкодження рани [21]. Одним з основних сучасних принципів лікування ран $є$ вологе ведення їх. Важливо підтримувати вологе середовище в рані для мітотозу, прискорення росту фібробластів, формування фібронектину, синтезу судинного фактора, дозрівання грануляційної тканини. Крім того, вологе середовище забезпечує високу активність ранових протеаз, попереджує висихання нервових закінчень (зменшення больового синдрому) [1, 2, 5, 29]. Також зменшуються запальна реакція, вираження рубцювання [26]. Дегідратація рани спричиняє втрату важливих білків, цитокінів, сповільнює міграцію клітин. Основним засобом для досягнення вологого середовища в рані є сучасні пов'язки для різних фаз ранового процесу, універсальної пов'язки не існує [25]. Крім пов'язок, є і інші методики, які сприяють природному клімату рани: препарати на гідрофільній основі, VAC-терапія, проточно-промивне дренування рани та ін. [4, 13]. Крім патогенетичного, слід враховувати також і етіологічний мікробний чинник. Препарати для місцевого лікування ран, матеріал пов'язок рекомендовано застосовувати, враховуючи ступінь їх цитотоксичної дії, ангіогенез (індекс біосумісності). Деякі з антисептиків подовжують фазу запалення, інгібують формування колагену, пошкоджують грануляції та можуть бути причиною розповсюдження гнійного процесу внаслідок порушення захисних бар'єрів. Пов'язки мають виконувати три основні функції: 1) поглинати рановий вміст; 2) забезпечити оптимальний водо-, повітро-, теплообмін між раною та зовнішнім середовищем; 3) ізолювати рану від мікроорганізмів та бути атравматичними $[1,5]$. Перспективою у використанні сучасних інтерактивних пов'язок, які створюють оптимальне середовище для загоєння, можуть служити засоби доставки лікарських засобів. За походженням їх поділяють на природні та синтетичні $[1,20,23]$. За цільовомим призначенням виділяють пов'язки антисептичні, протизапальні, гемостатичні, сорбуючі, ензимні, неадгезивні [5]. За своїми функціями їх ділять на сорбційні, захисні, активовані лікарськими засобами, атравматичні [1]. За структурними характеристиками ранові покриття можна класифікувати таким чином: 1) плівкові; 2) гідроколоїдні; 3) гідрофібри; 4) альгінати; 5) колагенові; 6) гідроцелюлярні; 7) гідрогелеві; 8) атравматичні; 9) сорбуючі; 10) комбіновані [2]. На сучасному етапі розробляються ранові покриття 3 новими властивостями: біоелектричні пов'язки
(Procellera) [24]; біодеградуючі нанофіброзні багатошарові мембрани з антибіотиками, на основі колагену; модифіковані гібридні пов'язки, вкриті нанодисперсією магнетиту i фітоантисептиків [22]; лікарські форми, збагачені бактеріофагами, 3 високоселективною бактерицидною дією та здатністю руйнувати біоплівки [12]. Останнім часом у лікуванні ран спостерігається також біоінженерний підхід 3 метою відновлення цілісності тканин, введення в рану синтетичних елементів міжклітинного матриксу, використання стовбурових клітин, препаратів пуповинної крові, кріоконсервованих та диплоїдних фібробластів, факторів росту [1, 5, 21].

Одним із перспективних напрямків $\epsilon$ використання іммобілізованих форм сорбентів. Застосування сорбційного дренажу приводить до зменшення навантаження на лімфатичну систему, оскільки разом з гранулами сорбенту при перев'язках видаляються некротичні тканини, антигени та білковоклітинні конгломерати [7]. Використовуються також форми сорбентів, поєднаних з антисептиками, протеолітичними ферментами, анестетиками [4].

Серед методів фізичного впливу на рану на першому місці стоїть закрита вакуум-асистована терапія (vacuum-assisted closure therapy) - VAC. В іiї основі лежить принцип безперервного або дискретного вакуумного розрідження в ділянці рани, що може поєднуватись із переміжним промиванням рани антисептиками чи без нього. Показаний цей метод для лікування гнійних та в'ялогранулюючих ран. Клінічними ефектами застосування є: зникнення болю, регресія набряку, очищення ран від фібрину та некрозу, зменшення бактеріального забруднення рани, скорочення площі й глибини ран, посилення місцевого кровотоку, підсилення ефекту медикаментозного лікування, формування повноцінних грануляцій та прискорення крайової епітелізації [13]. Однак деякі рандомізовані дослідження не вказують на значну перевагу VAC відносно традиційних методів лікування [28]. Також залишається дискутабельним питання щодо зменшення кількості мікроорганізмів у рані після курсу VAC [27]. Протипоказання до VAC: малігнізація; несанований остеомієліт; кровотеча; некротичні рани та рани з вираженою рубцевою тканиною; кишкові нориці; рани, стінками яких $є$ внутрішні органи, судини, зв’язки, нерви [13].

Лікування NO-вмісним плазмодинамічним газовим потоком набуває широкого застосування в країнах СНД (апарат “Плазон”). Основа методу - утворення оксиду азоту з потоку повітряної плазми при температурі 3000-3500 ${ }^{\circ} \mathrm{C}$. Клінічний ефект застосування характеризується регресією 
запальних явищ, скороченням всіх фаз ранового процесу, зменшенням бактеріального забруднення рани, індукцією фагоцитозу, можливістю виконати безкровну і точну некректомію [20].

Інтенсивно розвиваються методики використання ультразвукових хвиль у лікуванні ран, в яких виділяють два напрямки: “ультразвуковий скальпель” та озвучування рани (ультразвукова кавітація) [10]. Основним лікувальним фактором низькочастотного УЗ є механічне очищення рани за рахунок дезінтеграції некротизованих тканин та їх елімінації з рани. Клінічні ефекти впливу ультразвуку на рану: 1) зменшення перифокального набряку та мікробного забруднення, активне очищення ран, активація фагоцитозу; 2) посилення процесів утворення колагенових та еластинових волокон; 3) стимуляція росту капілярів, покращення нервової провідності; 4) посилення дії антибактеріальних препаратів; 5) гемостатичний (крім середньочастотного) та аналгезивний ефекти [6, 20].

Ефективним методом лікування ран, особливо при наявності анаеробних мікроорганізмів, $є$ гіпербарична оксигенація (ГБО). Усувається гіпоксія, здійснюється бактерицидна, дезінтоксикаційна дія, стимулюються репаративні процеси, активізується фагоцитоз, підвищується чутливість до антибіотиків $[1,10]$. Однак, тривала ГБО сповільнює процеси загоєння внаслідок пригнічення синтезу колагену та сповільнення ангіогенезу [1].

Близьким за фізіологічною дією в лікуванні ран є озонотерапія (ОЗТ) ран. Залежно від методу застосування ОЗТ поділяють на аераційну та інстиляційну. Ії застосування характеризується рядом ефектів: 1) антимікробним, противірусним, фунгіцидним; 2) протизапальним, імуномодулюючим; 3) покращенням мікроциркуляції та реології крові; 4) покращенням оксигенації тканин; 5) нормалізацією перекисного окиснення ліпідів та антиоксидантної системи; 6) впливом на тромбоцити (виділення факторів росту); 7) стимуляцією кісткового мозку [14]. Однак наявність великої кількості ексудату інактивує озон та зменшує його лікувальний ефект [9].

Одним 3 ефективних безпов'язкових методів лікування гнійних ран $є$ створення абактеріального середовища довкола рани - гнотобіологічного ізолятора із заданими параметрами мікроклімату. Показаннями до його використання $є$ великі площинні рани м'яких тканин, гнійно-некротичні рани, кукси після ампутацій, опіки, рани і виразки, які тривалий час не загоюються, бешиха [1]. Недостатком методу є його технічна складність, висока вартість, тривала іммобілізація хворого.

Віднедавна використовується лазерне випромінювання, яке поділяють на високо- та низькоінтен- сивне. Перше застосовується як “лазерний скальпель” для абляції, “випаровування” тканин при некректомії, зменшення мікробного забруднення рани, використовується при очищенні рани [1, 17]. Однак утворення шару коагуляційного некрозу не дозволяє рані загоїтися первинним натягом, тому немає переваг перед звичайною хірургічною обробкою, за винятком позитивного ефекту стерилізації рани [10]. Низькоінтенсивне лазерне випромінювання має протизапальну, знеболювальну дію, стимулює фагоцитоз, зменшує нейтрофільну інфільтрацію, покращує мікроциркуляцію, підвищує чутливість мікроорганізмів до антибіотиків, інгібує гіперпроліферативні процеси, має імунокоригувальну дію. Як варіант з метою прискорення загоєння ран використовуюють внутрішньосудинне лазерне опромінення крові (ВЛОК) [17].

Одним із видів фотолікування $є$ використання ультрафіолетових (УФ) променів, які поділяють на короткі (UVC) - мають високий антимікробний ефект, середні (UVB) - застосовують для стимуляції імунітету та процесу загоєння, а також в опроміненні крові (УФОК), та довгі (UVA) - впливають на сигнальні клітини рани. Перспективним $€$ використання, як доповнення до хірургічної обробки, гідропресивної терапії - обробка рани пульсуючим струменем антисептика під перемінним тиском 3 одночасною аспірацією вмісту рани. Метод дозволяє значно знизити мікробне забруднення рани, з недоліків - створення мікробного аерозолю в приміщенні [1].

Знайшло своє місце і використання екстремальних температур - гіпертермія та кріолікування. Місцевий вплив підвищеної температури дозволяє значно знизити бактеріальну забрудненість, зменшити прояви інтоксикації, запальних явищ, прискорити появу грануляцій [18]. Застосування кріотехнологій достовірно знижує кількість мікроорганізмів у рані нижче критичного рівня, зменшує ацидоз ранового вмісту, підвищує бактерицидну та фагоцитарну активність лейкоцитів. Заморожені тканини в подальшому відторгаються, залишаючи чисту рану.

Останніми роками розробляються методи імунокорекції гнійно-запальних захворювань. Помітні імунні зрушення при недостатній хірургічній обробці рани [10]. Імунокорекцію здійснюють шляхом застосування екстракорпоральних методів, пасивною імунізацією імуноглобулінами, пов'язками 3 імуномодулюючими властивостями $[10,19]$.

Висновки. Огляд літератури показав, що не існує універсального методу лікування гнійних ран, кожна з наведених методик має свої переваги та недоліки, обмежена часовими межами, фазністю перебігу ранового процесу. Однак знання патогенезу, 
алгоритмізація в лікуванні ран, ретельне врахування всіх переваг та недоліків, протипоказань до кожної з лікувальних методик дозволяють досягти максимально сприятливих результатів лікування. Тим не менше, не слід припиняти пошуків, розробку нових та вдосконалення вже відомих методик, спираючись на нові досягнення науки й техніки. Невирі-

\section{СПИСОК ЛІТЕРАТУРИ}

1. Абаев Ю. К. Справочник хирурга. Раны и раневая инфекция / Ю. К. Абаев. - Ростов-на-Дону : Феникс, 2006. - 427 с. 2. Андреев Д. Ю. Современные раневые покрытия. Часть І. / Д. Ю. Андреев, Б. А. Парамонов, А. М. Мухтарова // Вестник хирургии. - 2009. - Т. 168, № 3. - С. 98-101.

3. Бесчастнов В. В. Совершенствование активной хирургической тактики лечения больных с инфицированными ранами мягких тканей : дис. ... доктора мед. наук : 14.01 .17 : защищена 24.09.14 / Бесчастнов Владимир Викторович. - Н. Новгород, 2014. - 231 с.

4. Блатун Л. А. Местное медикаментозное лечение ран / Л. А. Блатун // Хирургия. Журнал им. Н. И. Пирогова. - 2011. - № 4. - С. 51-59.

5. Бледнов А. В. Перспективные направления в разработке новых перевязочных средств / А. В. Бледнов // Новости хирургии. - 2006. - Т. XIV, № 1. - С. 9-19.

6. Гостищев В. К. Инфекция в хирургии : руководство для врачей / В. К. Гостищев. - М. : ГЭОТАР-Медиа, 2007. С. 46-77.

7. Иммобилизированные формы антисептиков для лечения гнойных ран в эксперименте / А. Ю. Григорьян, А. И. Бежин, Т. А. Панкрушева [и др.] // Курский научно-практический вестник “Человек и его здоровье”. - 2011. - № 4. - С. 24-32.

8. Даценко Б. М. Патогенетическое обоснование местного лечения очагов гнойной инфекции / Б. М. Даценко [та ін.] // Клінічна хірургія. - 2007. - № 11-12. - С. 19.

9. Загиров У. 3. Озоно-магнитоферез в лечении гнойной раны / У. З. Загиров, У. М. Исаев, М. А. Салихов // Вестник новых медицинских технологий. - 2007. - T. XIV, № 3. - С. 207-208.

10. Кузин М. И. Раны и раневая инфекция. - 2-е изд. / М. И. Кузин, Б. М. Костюченок. - М. : Медицина, 1990. - 592 с.

11. Кузнецов Н. А. Щадящие хирургические вмешательства и интерактивные повязки в лечении инфицированных ран / Н. А. Кузнецов, В. Г. Никитин // Consilium medicum. Хирургия. - 2006. - № 2.

12. Лігоненко О. В. Використання бактеріофагів у комплексі лікування хронічних ран / О. В. Лігоненко [та ін.] // Клінічна хірургія. - 2011. - № 11. - С. 29.

13. Оболенский В. Н. Вакуум-терапия в лечении ран и раневой инфекции / В. Н. Оболенский [и др.] // РМЖ “Хирургия”. - 2010. - Т. 18, № 17. - С. 1064-1072.

14. Оболенский В. Н. Применение метода локального отрицательного давления в комплексном лечении острых гнойновоспалительных заболеваний мягких тканей / В. Н. Оболенский [и др.] // Хирургия. Журнал им. Н. И. Пирогова. - 2012. - № 12. - С. 50-55.

15. Оболенский В. Н. Хроническая рана: обзор современных методов лечения / В. Н. Оболенский // РМЖ “Хирургия”. 2013. - № 5. - С. 282-289.

16. Радзіховський А. П. Фактори виникнення ранової хірургічної інфекції / А. П. Радзіховський [та ін.] // Клінічна хірургія. - 2007. - № 11-12. - С. 52. шеними залишаються питання широкого радикалізму первинної хірургічної обробки в світлі нових методик лікування гнійних ран 3 акцентом на косметичні наслідки та віддалені результати. Наявність методик, що використовують різноманітні фактори впливу на рановий процес, дозволяє використати індивідуальний підхід до кожного хворого.

17. Современные аспекты лазерной терапии / под ред. В. Д. Попова. - Черкассы : Вертикаль, издатель Кандыч С. Г., 2011. - 608 с. 18. Фурманов Ю. А. Создание экспериментальных моделей инфицированных ран с последующей термоструйной обработкой / Ю. А. Фурманов [та ін.] // Клінічна хірургія. - 2008. - № 11-12. - С. 24-25.

19. Халилов М. А. Изучение иммунного статуса больных гнойными ранами на фоне локальной иммунокоррекции // Вестник новых медицинских технологий / М. А. Халилов, И. А. Снимщикова. - 2010. - Т. XVII, № 1. - С. 101-104.

20. Шабловская Т. А. Современные подходы к комплексному лечению гнойно-некротических заболеваний мягких тканей / Т. А. Шабловская, Д. Н. Панченков // Вестник экспериментальной и клинической хирургии. - 2013. - T. VI, № 4. - С. 498-507.

21. Современные возможности комплексного лечения гнойных ран / Ю. Л. Шевченко, Ю. М. Стойко, А. Л. Рябов, В. В. Кулабухов // Вестник Национального медико-хирургического Центра им. Н. И. Пирогова. - 2009. - Т. 4, № 2. - С. 9-12.

22. Anghel I. Modified wound dressing with phyto-nanostructured coating to prevent staphylococcal and pseudomonal biofilm development / I. Anghel // Nanoscale Research Letters. - 2012. Vol. 7. - P. 690.

23. Erfurt-Berge C. Recent developments in topical wound therapy: impact of antimicrobiological changes and rebalancing the wound milieu / C. Erfurt-Berge, R. Renner // BioMed Research International (issue ID 819525), Hindawi Publishing Corporation Date Views 14.01.2015 www.dx.doi.org/10.1155/2014/819525.

24. Antibacterial efficacy testing of a bioelectric wound dressing against clinical wound pathogens / K. Hosan, I. Makin, J. Skiba [et al.]. The Open Microbiology Journal. - 2014. - Vol. 8. P. 15-21.

25. Jones V. ABC of wound healing. Wound dressings / V. Jones, J. E. Grey, K. G. Harding // BMJ. - 2006. - Vol. 332 (1 April). P. 777-780.

26. Clinical impact upon wound healing and inflammation in moist, wet, and dry environments / J. P. E. Junker, R. A. Kamel, E. J. Caterson, E. Eriksson // Advances In Wound Care. - 2013. Vol. 2 (7). - P. 348-354.

27. The Effect of Vacuum-Assisted Closure on the Bacterial Load and Type of Bacteria: A Systematic Review / A. S. P. Patmo, P. Krijnen, W. E. Tuinebreijer, R. S. Breederveld // Advances in Wound Care. - 2013. - Vol. 3 (5). - P. 383-389.

28. Peinemann F. Negative-Pressure Wound Therapy. Systematic Review of Randomized Controlled Trials / F. Peinemann, S. Sauerland // Deutsches Ärzteblatt International. - 2011. - Vol. 108 (22). - P. 381-389.

29. Hydrocellular Foam Dressing Promotes Wound Healing along with Increases in Hyaluronan Synthase 3 and PPAR $\alpha$ / T. Yamane, G. Nakagami, S. Yoshino [et al.] // Gene Expression in Epidermis. PLOS ONE. - 2013. - Vol. 8 (Issue 8). Date Views 20.03.2014 www. journals.plos.org/plosone/article?id=10.1371/ journal.pone.0073988.

Отримано 18.03.15 